\title{
Theoretical and experimental investigation on internal reflectors in a single-slope solar still
}

\begin{abstract}
This study investigated the effect of an internal reflector (IR) on the productivity of a singleslope solar still (during the summer and winter) experimentally and theoretically. A mathematical model was presented which took into account the effect of all walls (north, south, west and east) of the still on the amount of received solar radiation to brine, and the model was validated with the experimental data. The model can calculate the yield of the still with and without IR on various walls. The results show that the simultaneous use of IR on front and side walls enhances the stillôs efficiency by $18 \%$. However, installation of an IR on the back wall can increase the annual efficiency by $22 \%$. The installation of IRs on all walls in comparison to a still without IR can increase the distillate production at winter, summer and the entire year by $65 \%, 22 \%$ and $34 \%$, respectively. Furthermore, the effect of cloud factor on the installation of IRs on all walls was examined, and the results indicate that the increasing the cloud factor decreases the influence of IRs significantly.
\end{abstract}

Keyword: Basin solar still; Internal reflector; Radiation model; Cloud factor; Solar desalination 